\title{
Effect of Turkish Bank Capital Structure of Basel II Criteria
}

\author{
Hüseyin Serdar YALÇINKAYA \\ Selçuk University, Konya, Turkey \\ Mehmet Ali AKTAŞ \\ Ufuk University, Ankara, Turkey
}

\begin{abstract}
Performing the functions of the bank's own funds lack of funds, those living in them to pass on more of those who use and quite a large amount of capital to determine the risks and managing them are facing. Chain of crises in financial markets spread to other sectors see that starting. This phenomenon depending on the potential risks of financial market actors, and especially banks, system identification, measurement, and control needs to be increased. This is referred to as the Basel Accords, depending on the needs the agreement of risk management has emerged. At first glance, the Basel II Accord in terms of risk management in financial institutions risk management recommendations to the perception of the principles of the Basel II Accord, but with a specific timetable, gradually emerges as a set of rules that must be passed as risk management. Finally, the financial crisis spread across the world from the United States, how much it reveals that risk management in the financial markets. In this study, capital adequacy ratio (CAR) banks operating in Turkey's correlation analysis investigated the effect of the banks.
\end{abstract}

Keywords: Basel II, capital adequacy ratio (CAR), crisis, risk

\section{Introduction}

The basic principles of operation of banks and other financial intermediaries to raise funds, and these funds in the market to provide people with lack of funds and profits which together to provide the so-called spread. However, the present banking and other financial transactions has increased even more There are risks all along. Banks are where the problem unless directed towards these risks but they conduct their major losses and faced a fact wrong.

Basel Committee accordingly formed with the purpose of standardization of Basel criteria for risk management of banks, but was insufficient in the face of emerging financial markets and financial risks. Accordingly, the committee created the banks Basel II criteria, these criteria for a period of time as the initial advisory although many countries have adopted their own standards, these criteria.

BRSA on this subject, and asked him to implement the application in this regard gradual transition to the application banks set schedule. Depending on the criteria of the Basel II Capital Adequacy Ratio of Banks standards, since 2003, have begun to measure. In this context the College of Health study data showed changes in banks' profitability and non-performing loans, and this ratio depending on the relative positions examined.

Hüseyin Serdar YALÇINKAYA, Ph.D., Assistant Professor, Ereğli Kemal Akman Vocational School, Selçuk University. Mehmet Ali AKTAŞ, Ph.D., Assistant Professor, Faculty of Economics and Administrative Sciences, Ufuk University.

Correspondence concerning this article should be addressed to Mehmet Ali AKTAŞ or Hüseyin Serdar YALÇINKAYA. E-mail: maktas978@gmail.com; hsy3@mynet.com. 


\section{Basel Accord and Historical Development}

Before the establishment of the review at the BIS in Basel to examine the historical development of accords required. BIS, May 17, 1930, was established in order to regulate the international payments system. BIS, in the 1960s, has made significant efforts to ensure the functioning of the Bretton Woods system, worked in the oil crises of the 1980s, followed by the disruption payments system. Efforts to create a collaborative forum for central banks, as well as to conduct research and to provide recommendations to the stability of international markets (e.g., capital adequacy ratio) with tasks such as the BIS, the central bank for its customers and international organizations engaged in core banking activities.

There are 17 members of the BIS Board of Directors, six main members (Belgium, France, Germany, Italy, UK, and the U.S. Central Bank Chairman of the Board of Heads of Central Banks) and six additional member to be elected from their own countries, as well as of those members, elected five members (Canada, Japan, the Netherlands, Sweden, and the Switzerland) are available.

Bankhaus I.D. Herstatt'in in Germany in 1974 led to bankruptcy of the international monetary and banking areas have serious problems, and in the same year by the Heads of the Central Bank of G-10 countries, banking regulations and supervision of the Basel Committee, an international committee was established to work on. Belgium, Canada, France, Germany, Italy, Japan, Luxembourg, the Netherlands, Switzerland, Sweden, the United Kingdom, and the United States is a member of the committee held its first meeting in February of 1975. From this date, the Committee continues to work through meetings held 3-4 times per year. In 1975, the Committee issued the "Basel Concordat" I first official document of this cooperation on banking regulation and supervision. This document is an international bank with a branch located in the center of the country in which the relations between the country's regulatory and supervisory authorities, and clearly defines the rights and responsibilities of each authority. In May 1983, in parallel with the changes in this document, the updated and improved form in the banking sector, published under the name of "Foreign Bank Branches Oversight Principles" (BIS, 1997).

Basel I Regulations. Internationally active banks in the early 1980s due to the heavily indebted countries as a result of concerns over risks plus it reduces the capital adequacy of banks, the G-10 countries at the request of the Central Bank of the Basel Committee on banking systems and capital adequacy measures to stop erosion of the current capital standards to ensure the harmonization of started to work. Increase the stability of the international banking system, international capital framework of the Committee, as well as at the national level would eliminate inequality between different competition from capital adequacy regulations are of the opinion.

The first risk-based capital adequacy of banking regulation at the international level, the Basel I is put into effect in 1988. For the first time in this embodiment, "Cook Ratio" referred to as the capital adequacy ratio is presented. Only to credit risk sensitive capital accord established a capital adequacy ratio. "Capital Accord" approach initially proposed for internationally active banks, while the expected course of time accepted and adopted and implemented more than 100 countries.

Even if no sanction for the implementation of the G-10 countries, this non-editing eventually found it is not a coincidence that a wide range of applications. Held in Stockholm, Sweden, in 1996, "Ninth International Conference on Banking Supervision" of participating in a survey of 129 representatives of these countries, $90 \%$ of the country's Basel Capital Regulation has been implemented similar approach to risk-weighted 
capital base.

$$
\text { Basel Capital Adequacy Ratio }=\text { Capital/Credit Risk } \geq 8 \% \text { (Cook Ratio) }
$$

Basel II Regulations. The New Basel Capital Accord (Basel II), banks' capital adequacy in relation to the measurement and evaluation of the Basel Committee on Banking Supervision (Basel Committee on Banking Supervision-BCBS) issued by the recently expected to be enacted in many countries, a set of standards developments in the international markets, the current arrangement is inadequate in the face of changing conditions, such as increased risk types of elements required to create the new capital standards. From this point of emergence period satisfies the requirements of Basel I, risk measurement, but is now missing due to lack of structure has become a practice. In this context, a first draft text was released in June 1999, "Basel II Capital Accord", which aims to achieve more accurate risk measurement has been proposed as a regulation. Banks' credit risk assets, which are subject classification of a new arrangement with a counterparty, the credit worthiness of counterparties issued to the forefront of national supervisory authorities highlighted the importance of controls and disclosure requirements, steps have been taken towards ensuring transparency in determining (BBDDK, 2005, p. 15).

Editing in drafts presented to the public at different times and most recently in June 2004 to discuss the latest shape achieved by giving "Basel II Accord 2.Sermaye". The final text was published under the name of Arrangements, although it seemed to Basel capital adequacy calculation, requires very detailed data and analysis of the risk profile of the bank's healthy and beyond the legal requirements, it is necessary to enable risk management

\section{Basel II Accord Banking Risks}

Basel II Accord, both simple as well as a conceptual opening is quite comprehensive discussed under three main headings banking risks taken, as well as the need to identify the risks in banking risk management measure, allowing the formation of an international association contributed to a very important function.

Credit risk, market risk, and operational risk, the risk of such types, scopes width and therefore carry a high importance in both theoretical and in practice has become a separate field of expertise. In this regard, the width of coverage of types of risk as well as the effect of the complex structure of internal models used in metering is great.

Despite the emergence of banking has been around since the early times, wherein the measurement of the risks facing the real acceleration in the development of advanced methods, but could move come at the beginning of the 1990s. The most important factor in this, especially in complex and comprehensive data collection and processing of a large number of approaches is that allow for the needed quantity of developments in computer technology.

Market risk. Market risk, depending on the change in prices of banks' on-balance sheet and off-balance sheet positions is the probability of the harm (Basel Committee, 1996). Defining a glance market risk, risk factors refers to possible losses arising from changes (Don, 2001, p. 690). The Committee formed the origin of the mentioned risk factors, interest rate risk, foreign exchange risk, equity price risk shares, commodities (commodity) price risk and option risk to be subsumed under five separate headings.

Market risk includes virtually all banking transactions. However, the new regulation, the prices adapted to the market on a daily basis, and thus the grounds that it has become possible to conduct the calculations correctly, especially focuses on trading portfolios (Hendricks \& Hirtle, 1997, p. 2). Performed to Basel I 
Accord this additional regulation, price risks arising from trading transactions is intended to provide protection against the banks, the capital safe. A new element of risk than credit risk, market risk measurement-oriented studies, especially in the banking sector to the crisis in the financial markets and the impact of the increase in the sensitivity gradually realized quite extensively, in this context, important progress has been made, including new methods of statistical measurement, advanced statistical methods used in the measurement of risk for the first time. By the Committee as a standard approach towards the measurement of market risk and the internal measurement approach are presented in two separate options (Hendricks \& Hirtle, 1997, p. 2). Basel II Accord, the measurement of market risk, in addition to regulation of 1996 there was no need to make a significant change.

Credit risk. Credit risk, in general, the bank customer (or agreement against the side) is defined as the probability of failing to meet its obligations in accordance with the conditions specified in the contract. Loans granted by banks, but the most important element of credit risk, especially in recent years, a growing inter-bank money market transactions, foreign exchange transactions, guarantees and sureties, bond market operations and investment in derivatives transactions, such as the banks faced another important source of credit risk (Basel Committee on Banking Supervision Report, 2000, p. 1).

Taken within the framework of the bankruptcies, the credit risk is seen that the main risk in the capital markets (van Deventer \& İMAI, 2003, p. 5). This is a very important part of the Bank's balance sheet to be faced because of the element of risk, credit risk management is of great importance for banks. Banks and credit portfolio as a whole as well as each of the individual are required to manage the risk of carrying the loan.

Credit risk is very important for measuring progress which has been made in recent years. Increase in the Bank's bankruptcy, your credit rating with a low increase in the number of medium and small sized companies, it has become a highly competitive loan interest rates, and fluctuations in real estate values, and therefore the decline in the value of collateral, the rapidly growing off-balance sheet transactions, other factors such as technological advances provide great advances in computer systems, credit played an important role in the emergence of innovation-oriented measurement of risk. All these factors are mentioned as well as another important element in directing banks to use new methods of measurement, however, is to bankrupt a company with the highest credit ratings in assessing the level of a firm in the same risk and the same capital requirement Basel I Accord which has been measured on the lack of (Saunders, 1999, p. 4).

As a result of the work carried out over the years to the development and use of certain conditions by the banks which created the new Basel Acoord approaches to measuring credit risk methods of measurement, based on previous accord has been made almost entirely by changing market conditions and requirements.

Operational risk. In terms of risk than other banking finance literature has recently started to be is being described as operational risk in general risks other than credit risk, market risk. Some studies represent the operational risk theory (agency theory) are associated. Representing risk, business owners devretmesiyle management authority managers are emerging. Always conflict between the interests of the parties is the origin of the problem (Sheedy, 1999, p. 8). Information asymmetry due to the difference in interest between the parties over time (the disproportionate distribution of information), operational risk is a very important source. Operational risk, credit risk or market positioning processes are occurring, in fact, the first type of risk faced by banks is considered (Hans, 2000, p. 1).

Personnel risk of mistakes conscious employees, process risk, omissions rules on the functioning of the 
institution and the system risk, the technological systems used in the involuntary interruptions, except for the effect of external risk developing the organization and operation of natural events represent losses caused by third parties (Harmantsiz, 2004, p. 2).

\section{Application}

In our study, the study of the banking sector Banks Association of Turkey in 2011 and this data are used in the actual data belongs to the years of 2002-2010. Banks' CAR cumulative net profit/equity and non-performing loans/total loans ratio and net profit data were used.

Correlation analysis of the profitability of the banks' response to the change data in the study, the College of Health and investigated whether there is a relationship between non-performing loans.

Table 1

Net Profits of Banks in Turkey

\begin{tabular}{lrrrrrrrr}
\hline & 2003 & 2004 & \multicolumn{1}{l}{2005} & \multicolumn{1}{l}{2006} & \multicolumn{1}{l}{2007} & \multicolumn{1}{l}{2008} & \multicolumn{1}{l}{2009} & \multicolumn{1}{c}{2010} \\
\hline Turkish banking system & $5,590,686$ & $6,391,220$ & $5,648,912$ & $11,101,115$ & $14,565,266$ & $12,986,576$ & $19,477,317$ & $2,136,0250$ \\
Deposit money banks & $5,105,613$ & $5,988,643$ & $4,793,319$ & $10,242,578$ & $13,466,696$ & $11,851,867$ & $18,489,700$ & $20,518,216$ \\
State-owned deposit money banks & $1,790,361$ & $2,682,316$ & $2,869,057$ & $3,733,230$ & $4,512,830$ & $3,905,772$ & $6,393,252$ & $6,880,135$ \\
Privately owned deposit money banks & $2,339,913$ & $2,174,115$ & 283,380 & $4,543,043$ & $7,154,752$ & $6,480,777$ & $9,974,953$ & $11,683,220$ \\
Foreign banks & 693,995 & 745,871 & $1,381,437$ & $1,574,802$ & $1,694,809$ & $1,384,868$ & $2,066,983$ & $1,952,850$ \\
Development and investment banks & 400,495 & 315,145 & 682,624 & 738,646 & 863,539 & 922,198 & 987,617 & 842,034 \\
\hline
\end{tabular}

Note. Source: TBB (Banks Association of Turkey), 2012. Retrieved from http://www.tbb.org.tr.

Table 2

Banks in Turkey Cumulative CAR Data

\begin{tabular}{|c|c|c|c|c|c|c|c|c|c|}
\hline & \multicolumn{9}{|c|}{ Equity/(Amount subject to credit + market + operational risk) } \\
\hline & 2010 & 2009 & 2008 & 2007 & 2006 & 2005 & 2004 & 2003 & 2002 \\
\hline Turkish banking system & 19.2 & 20.9 & 18.1 & 19.1 & 22.0 & 24.2 & 28.8 & 30.9 & 24.2 \\
\hline Deposit money banks & 17.7 & 19.3 & 16.5 & 17.4 & 19.8 & 21.6 & 26.2 & 28.1 & 23.1 \\
\hline State-owned deposit money banks & 16.7 & 18.4 & 16.4 & 20.1 & 29.1 & 37.7 & 37.1 & 56.3 & 50.2 \\
\hline Privately owned deposit money banks & 18.2 & 19.7 & 16.4 & 17.2 & 17.5 & 17.2 & 22.3 & 23.5 & 19.7 \\
\hline Foreign banks & 17.3 & 18.8 & 16.7 & 14.5 & 16.0 & 17.4 & 26.9 & 36.2 & 32.6 \\
\hline Development and investment banks & 58.6 & 60.3 & 59.4 & 66.7 & 86.2 & 104.3 & 90.4 & 78.4 & 40.2 \\
\hline
\end{tabular}

Note. Source: TBB (Banks Association of Turkey), 2012. Retrieved from http://www.tbb.org.tr.

Table 3

Banks in Turkey Cumulative Net Profit/Equity Data

\begin{tabular}{|c|c|c|c|c|c|c|c|c|c|}
\hline & \multicolumn{9}{|c|}{ Net profit (Loss)/Equity } \\
\hline & 2010 & 2009 & 2008 & 2007 & 2006 & 2005 & 2004 & 2003 & 2002 \\
\hline Turkish banking system & 16.5 & 18.3 & 15.4 & 19.5 & 18.9 & 10.6 & 14.0 & 15.8 & 9.2 \\
\hline Deposit money banks & 17.8 & 19.7 & 16.4 & 20.9 & 20.3 & 10.6 & 15.0 & 16.5 & 8.3 \\
\hline State-owned deposit money banks & 23.4 & 27.2 & 22.5 & 26.8 & 25.1 & 21.6 & 26.6 & 18.7 & 15.7 \\
\hline Privately owned deposit money banks & 17.6 & 18.5 & 15.8 & 19.9 & 16.9 & 4.7 & 10.3 & 13.9 & 16.0 \\
\hline Foreign banks & 10.6 & 13.1 & 10.5 & 15.2 & 20.5 & 15.5 & 11.9 & 11.2 & 5.9 \\
\hline Development and investment banks & 6.0 & 7.8 & 8.7 & 9.6 & 9.8 & 10.9 & 6.1 & 10.6 & 15.5 \\
\hline
\end{tabular}

Note. Source: TBB (Banks Association of Turkey), 2012. Retrieved from http://www.tbb.org.tr. 
Table 4

Banks in Turkey Cumulative Non-performing Loans/Total Loans Data

\begin{tabular}{lcccccccccc}
\hline & \multicolumn{1}{c}{ Non-performing loans/Total loans } \\
\cline { 2 - 10 } & 2010 & 2009 & 2008 & 2007 & 2006 & 2005 & 2004 & 2003 & 2002 \\
\hline Turkish banking system & 0.6 & 0.8 & 0.7 & 0.4 & 0.3 & 0.5 & 0.7 & 1.4 & 6.6 \\
Deposit money banks & 0.6 & 0.9 & 0.7 & 0.4 & 0.4 & 0.5 & 0.8 & 1.5 & 7.3 & 0.5 \\
State-owned deposit money banks & 0.4 & 0.6 & 0.5 & 0.1 & 0.2 & 0.2 & 0.5 & 0.8 & 12.7 & 0.2 \\
Privately owned deposit money banks & 0.4 & 0.6 & 0.7 & 0.5 & 0.4 & 0.6 & 0.8 & 1.4 & 4.3 \\
Foreign banks & 1.3 & 1.9 & 1.0 & 0.6 & 0.3 & 0.7 & 0.8 & 1.0 & 1.1 \\
Development and investment banks & 0.3 & 0.5 & 0.1 & 0.1 & 0.1 & 0.1 & 0.3 & 0.3 & 1.1 \\
\hline
\end{tabular}

Note. Source: TBB (Banks Association of Turkey), 2012. Retrieved from http://www.tbb.org.tr.

\section{Findings}

Banks' net profit as a result of correlation analysis was performed between the data and the CAR data was higher for inter-relation between the level of significance was negative. Accordingly, the total of the entire banking sector, according to the number of correlation -0.766 indicate the existence of a relationship in reverse, and quite high. So banks fell between these periods CAR, profitability has increased.

Table 5

Correlation Results of All the Banks of Turkish Banking System

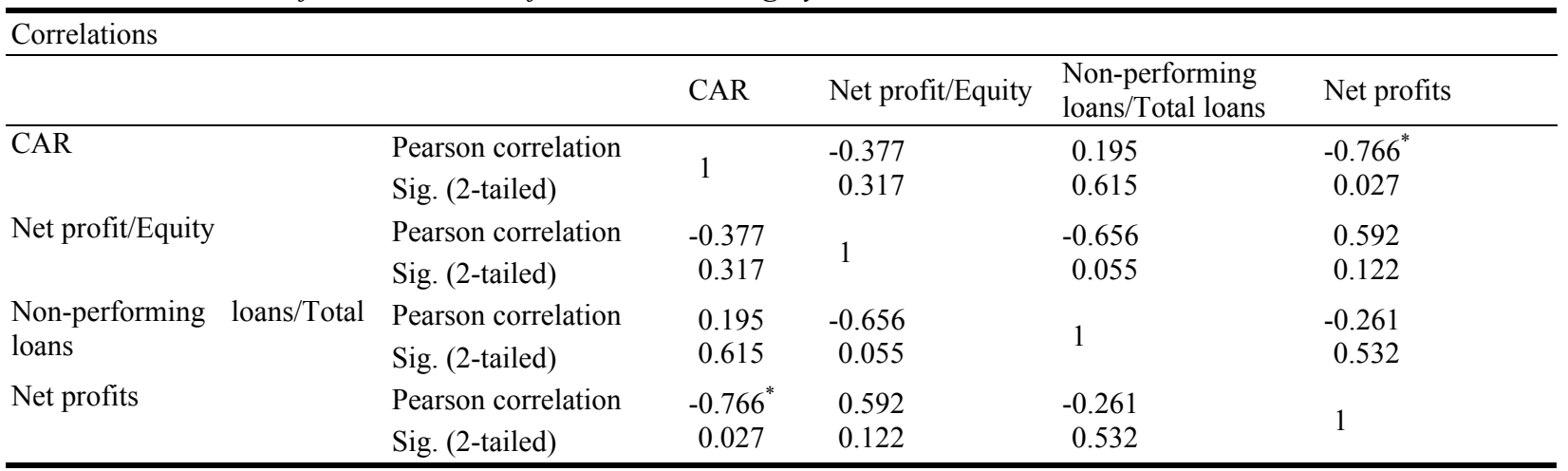

Note. ${ }^{*}$ Correlation is significant at the 0.05 level (2-tailed).

Table 6

Deposit Money Banks Correlation Results

\begin{tabular}{llllcc}
\hline Correlations & & & & \\
\hline & & CAR & $\begin{array}{l}\text { Net } \\
\text { profit/Equity }\end{array}$ & $\begin{array}{l}\text { Non-performing } \\
\text { loans/Total loans }\end{array}$ & Net profits \\
\hline CAR & Pearson correlation & 1 & -0.416 & 0.291 & $-0.714^{*}$ \\
& Sig. (2-tailed) & & 0.266 & 0.448 & 0.047 \\
Net profit/Equity & Pearson correlation & -0.416 & 1 & $-0.689^{*}$ & 0.614 \\
& Sig. (2-tailed) & 0.266 & & 0.040 & 0.106 \\
Non-performing & Pearson correlation & 0.291 & $-0.689^{*}$ & 1 & -0.264 \\
loans/Total loans & Sig. (2-tailed) & 0.448 & 0.040 & & 0.528 \\
Net profits & Pearson correlation & $-0.714^{*}$ & 0.614 & -0.264 & 1 \\
& Sig. (2-tailed) & 0.047 & 0.106 & 0.528 & \\
\hline
\end{tabular}

Note. ${ }^{*}$ Correlation is significant at the 0.05 level (2-tailed). 
Table 7

State-Owned Deposit Money Banks Correlation Results

\begin{tabular}{llllcc}
\hline Correlations & & & & \\
& & CAR & $\begin{array}{l}\text { Net } \\
\text { profit/Equity }\end{array}$ & $\begin{array}{l}\text { Non-performing } \\
\text { loans/Total loans }\end{array}$ & Net profits \\
\hline CAR & Pearson correlation & 1 & $-0.709^{*}$ & 0.492 & $-0.826^{*}$ \\
& Sig. (2-tailed) & & 0.032 & 0.178 & 0.011 \\
Net profit/Equity & Pearson correlation & $-0.709^{*}$ & & $-0.718^{*}$ & 0.489 \\
& Sig. (2-tailed) & 0.032 & 1 & 0.029 & 0.218 \\
Non-performing & Pearson correlation & 0.492 & $-0.718^{*}$ & & -0.147 \\
loans/Total loans & Sig. (2-tailed) & 0.178 & 0.029 & 1 & 0.729 \\
Net profits & Pearson correlation & $-0.826^{*}$ & 0.489 & -0.147 & 1 \\
& Sig. (2-tailed) & 0.011 & 0.218 & 0.729 & \\
\hline
\end{tabular}

Note. ${ }^{*}$ Correlation is significant at the 0.05 level (2-tailed).

Table 8

Privately Owned Deposit Money Banks Correlation Results

\begin{tabular}{lllllc}
\hline Correlations & & & & \\
& & CAR & $\begin{array}{l}\text { Net } \\
\text { profit/Equity }\end{array}$ & $\begin{array}{l}\text { Non-performing } \\
\text { loans/Total loans }\end{array}$ & Net profits \\
\hline CAR & Pearson correlation & 1 & -0.157 & 0.282 & -0.298 \\
& Sig. (2-tailed) & & 0.687 & 0.462 & 0.473 \\
Net profit/Equity & Pearson correlation & -0.157 & 1 & 0.026 & $0.800^{*}$ \\
& Sig. (2-tailed) & 0.687 & & 0.946 & 0.017 \\
Non-performing & Pearson correlation & 0.282 & 0.026 & 1 & -0.482 \\
loans/Total loans & Sig. (2-tailed) & 0.462 & 0.946 & & 0.227 \\
Net profits & Pearson correlation & -0.298 & $0.800^{*}$ & -0.482 & 1 \\
& Sig. (2-tailed) & 0.473 & 0.017 & 0.227 & \\
\hline
\end{tabular}

Note. ${ }^{*}$ Correlation is significant at the 0.05 level (2-tailed).

Table 9

Foreign Banks Correlation Results

\begin{tabular}{lllllc}
\hline Correlations & & & & \\
\hline & & CAR & Net profit/Equity & $\begin{array}{l}\text { Non-performing } \\
\text { loans/Total loans }\end{array}$ & Net profits \\
\hline CAR & Pearson correlation & 1 & -0.595 & 0.147 & $-0.791^{*}$ \\
& Sig. (2-tailed) & & 0.091 & 0.705 & 0.020 \\
Net profit/Equity & Pearson correlation & -0.595 & 1 & -0.540 & 0.209 \\
& Sig. (2-tailed) & 0.091 & & 0.133 & 0.620 \\
Non-performing & Pearson correlation & 0.147 & -0.540 & 1 & 0.393 \\
loans/Total loans & Sig. (2-tailed) & 0.705 & 0.133 & & 0.335 \\
Net profits & Pearson correlation & $-0.791^{*}$ & 0.209 & 0.393 & 1 \\
& Sig. (2-tailed) & 0.020 & 0.620 & 0.335 & \\
\hline
\end{tabular}

Note. ${ }^{*}$ Correlation is significant at the 0.05 level (2-tailed).

Net profit/equity ratios and results of the analysis are carried out by the College of Health. According to this data the relationship between the significant negative relationships between the data is attenuated total sector weakened. Relation is very weak, especially private banks. The reason for the increase in shareholders' 
equity corresponds to the College of Health required by the profitability and risks considered. However, the College of Health decreases in net profit/equity ratio was found to be increased.

The study of non-performing loans/total loans made in the search of the relationship between rates and CAR is not at the desired level of significance rates.

Table 10

Development and Investment Banks Correlation Results

\begin{tabular}{llllll}
\hline Correlations & & & & \\
\hline & & CAR & Net profit/Equity & $\begin{array}{l}\text { Non-performing } \\
\text { loans/Total loans }\end{array}$ & Net profits \\
\hline CAR & Pearson correlation & 1 & -0.326 & -0.653 & -0.637 \\
& Sig. (2-tailed) & & 0.392 & 0.057 & 0.090 \\
Net profit/Equity & Pearson correlation & -0.326 & 1 & 0.591 & 0.058 \\
& Sig. (2-tailed) & 0.392 & & 0.094 & 0.892 \\
Non-performing & Pearson correlation & -0.653 & 0.591 & 1 & -0.049 \\
loans/Total loans & Sig. (2-tailed) & 0.057 & 0.094 & & 0.908 \\
Net profits & Pearson correlation & -0.637 & 0.058 & -0.049 & 1 \\
& Sig. (2-tailed) & 0.090 & 0.892 & 0.908 & \\
\hline
\end{tabular}

Note. ${ }^{*}$ Correlation is significant at the 0.05 level (2-tailed).

\section{Results}

Basel criteria for this study, banks in Turkey, especially the capital adequacy ratio (CAR) has an impact on how it investigated. In this context profitability ratios of banks with CAR were found to be negative. Banks, while banks' CAR increased profitability ratios. Thus, the risks banks are more efficient than the use of equity was used.

In general, the principles of the Basel Accord have a positive impact on the Turkish banking sector. As a result, the crisis of 2008, the Turkish banking sector has prepared and equipped and has survived the crisis without any problems.

\section{References}

Altintaş, M. A. (2006). Bankacılıkta Risk Yönetimi ve Sermaye Yeterliliği. Turkey: Turhan Kitapevi.

Babuscu, Ş. (2003). Türk Bankacılık Sektöründe Beklentiler ve Gelişmeler. Ankara: Halkbankası, Eğitim Daire Başkanlığı.

Bankacılık Düzenleme ve Denetleme Kurumu. (2001). Bankacılık Sektörü Yeniden Yapılandırma Programı. Retrieved

$\begin{array}{llll}\text { September 20, 2005, from } & \text { 20 }\end{array}$

http://www.bddk.org.tr/turkce/yayinlarveraporlar/rapor/yapilandirmaprogrami/bank_yapilandirma_prog.doc

Bankacılık Düzenleme ve Denetleme Kurumu. (2005). Bankacılık Sektörü Risk Degerlendirme Raporu. Retrieved September 20, 2005, from http://www.bddk.org.tr/turkce/yayinlarveraporlar/yayinlarveraporlar.htm\#5

Basel Committee on Banking Supervision Report. (2000). Basel committee on banking supervision principles for the management of credit risk. Retrieved from http://www.bis.org/publ/bcbs75.pdf

Basel Committee on Banking Supervision. (1993). The supervisory treatment of market risks. Retrieved from http://www.bis.org/publ/bcbsc005.pdf

Carolyn, V. C. (2004). Basel-II and operational risk-Overview of key concerns. IQPC Operational Risk Forum, University of Technology, Sydney.

Don, M. C. (2001). An introduction to derivatives and risk management. Texas: Harcourt College Publishers.

Hans, G. (2000). Regulating and supervising operational risk for banks. Working Paper, University Of Zurich.

Harmantzis, F. C. (2003). Operational risk management. Retrieved from http://www.lionhtrpub.com/orms/orms-2_03/frrisk.html 
Hendricks, D., \& Hirtle, B. (1997). Bank capital requirements for market risk: The internal models approach. Economic Policy Review, 3(4), 1-12.

Küçüközmen, C. (1999). Bankacılıkta risk Yönetimi ve Sermaye Yeterliliği value at risk Uygulamaları. Iktisat Isletme ve Finans, 14(156), 71-87.

Matten, C. (2000). Managing bank capital: Capital allocation and performance measurement. New York: John Wiley. Saunders, A., \& Cornet, M. M. (2003). Financial inslihitions management. US: McGraw-Hill.

Sheedy, E. (1999). Applying an agency framework to operational risk management. CMBF Papers, No. 22 Applied Finance Centre, Macquarie University.

van Deventer, D. R., \& İmai, K. (2003). Credit risk models and the basel accords. US: Wiley Finance. 